\title{
Climate Resilient Maize Production in Chepang and Non-Chepang Farming Communities of Chitwan, Nepal
}

\author{
P. Sharma ${ }^{1 *}$, R. R. Kattel ${ }^{1}$, A.P. Subedi ${ }^{2}$ \\ ${ }^{1}$ Department of Agricultural economics and Agri-Business Management, AFU, Rampur, Chitwan, Nepal \\ ${ }^{2}$ Department of Agribotany and Conservation Ecology, AFU, Rampur, Chitwan, Nepal
}

\begin{abstract}
Article Information
Received: 12 January 2020

Revised version received: 14 March 2020

Accepted: 17 March 2020

Published: 29 March 2020

Cite this article as:

P. Sharma et al. (2020) Int. J. Appl. Sci. Biotechnol. Vol 8(1): 71-77. DOI: $10.3126 /$ ijasbt.v8i1.27242

\section{*Corresponding author}

Pratiksha Sharma,

Department of Agricultural economics and AgriBusiness Management, AFU, Rampur, Chitwan, Nepal Email: dhakalpratiksha10@gmail.com

Phone no: (+977)-9845708326

Peer reviewed under authority of IJASBT

(C) 2020 International Journal of Applied Sciences and Biotechnology

\section{OPEN}

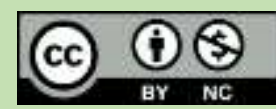

This is an open access article \& it is licensed under a Creative Commons Attribution Non-Commercial 4.0 International (https://creativecommons.org/licenses/by-nc/4.0/)

Keywords: Climate; Chepang; maize; adaptation
\end{abstract}

\begin{abstract}
This research was conducted to assess farmer's adaptation strategies of climate change in maize cultivation among Chepang and Non-Chepang communities in Chitwan. Pre-tested questioner, direct observation and secondary data were collected and used. Data analysis was done by using descriptive statistics, time series regression, Logit and seemingly unrelated regression model. Productivity of study area was found to be positively affected by total rainfall whereas negatively affected by average temperature. Majority of respondents $(86.7 \%)$ were found to adopt any one of the climate change related adaptation strategies on maize cultivation. Among various adaptation strategies, mix cropping $(66.3 \%)$ was found major in the study areas. Head of household, knowledge about climate change and economically active members in the family were positive determinant on adoption of climate change adaptation strategies.SUR model showed that education of household head, economically active member in the household, an involvement in extension/ training and maize production were major positively significant explanatory variables whereas age, gender of household head and involvement in an organization were major negatively significant explanatory variables in farmer's decision for adaptation of different climate change combating strategies. The study concluded that farmers of Chitwan perceived change in climate with negative effect on their maize cultivation practices. In comparison to Non-Chepang, Chepang farmers had less knowledge and adaptation practices. More focus from government and Nongovernment sector through proper policy implementation and technology intervention is needed to support this backward community.
\end{abstract}

\section{Introduction}

Maize (Zea Mays) is second most important staple food crop in Nepal after rice. It is cultivated in 2145291 hectare area with total production of 882395 metric tons and average productivity of 2400 kilograms per hectare (MoAD, 2016). The average optimum temperature for maize is $22-25^{\circ} \mathrm{C}$ (Bannayan et al. 2004). The Hill area that extended from east to west is the most important maize growing area. Hills of Eastern, Central and Western are highest maize yielding areas of country. Chitwan district ranks first in maize production followed by Kavre and Tanahun districts whereas highest productivity is at Kathmandu district. Changes in climate might have substantial effects on maize production. In context of Nepal, rose in temperature is favorable for growing maize in mountain in comparison to terai and hills (Nayava and Gurung, 2010) whereas rise in summer rainfall and maximum temperature negatively affect yield of maize (Joshi et al., 2011). 
Climate change has been a global threat and is challenging human livelihood. Developing countries like Nepal contribute less to global greenhouse emission but affected most by the effect of climate change. Contribution of Nepal is 0.025 percentages to greenhouse emission but is ranked 4th on Maplecorft's climate vulnerability index (Maolecorft, 2011). Nepal is experiencing rise in temperature, irregular onset of monsoon, erratic rainfall which has hiked out bursting vulnerability of Glacier Lake, landslide, flood, drought, increasing pest, disease and loss in yield. Temperature of the nation is increasing gradually (Shrestha et al., 2000; Ebi et al., 2007). Precipitation has been more erratic, unpredictable and heavy with more droughts and shorter periods of winter rainfall (Shrestha et $a l .$, 2000). Climate resilience is the capacity for a socioecological system to absorb stresses and maintain function in the face of external stresses imposed upon it by climate change and to adapt, reorganize and evolve into more desirable configurations that improve the sustainability of the system, leaving it better prepared for future climate change impacts. Adaptations to climate change reduce climatic vulnerabilities and help in utilizing opportunities provided by changing climate. This helps farmers in boosting up their innovation and self-dealing with adverse events.

Chitwan district, lying at the centre of Nepal is habitat for various communities like Chepang, Tharus, Darai, Bharmin, Chhetri etc. Some of these communities are forward and active whereas some are found to be highly backward. Chepangs, one of the most backward indigenous nationalities occupying $0.23 \%$ of the total population (CBS,2003) and lives in the wildest imaginable state of nature. Hills of Chitwan, Makwanpur, Dhadhing and Gorkha are major dwelling places for more than $95 \%$ of Chepang. Indigenous and local peoples remain close to the nature and develop adaptation strategy according to time relevancy. Chepang and local people of Chitwan are adapting their own strategies to cope with this changing climate. Most common climate change copping strategies by Chepang are shifting cultivation, adjustment in time of sowing, different soil conservation practices, varietal selection, wild edible collection, wage laboring, nonfarm job, rearing livestock, cash crops and water pond construction (Piya et al., 2013).

Till date, various studies can be seen regarding climate change but very nominal focus can be seen toward local and indigenous communities. This study has attempted to fill this vacancy by analyzing the impact of climate change on maize production and local and indigenous farmer's coping strategies. The overall objective of this study is to gather knowledge about climate change and agriculture along with different mitigation measure followed by different communities of Chitwan district. Findings of this research are useful for developing site-specific strategies of climate change, support the timely improvement of current policies, useful for stakeholders and policymakers of agricultural sector, poverty alleviation, food security, disaster management as well as can act as a supporting tool for upcoming researchers in the field of climate change and .communities of Chitwan district.

\section{Materials and Methods}

\section{Site Selection, Study population, Sample size and Sampling procedure}

For the purpose of study Fulbari and Shaktikhor village of Chitwan district were selected as study sites. Study populations were all farmers from Fulbari and Chepangs from Shaktikhor. In total 120 samples were selected where 60 respondents were selected from each village. Simple random sampling was used for sample selection.

\section{Data collection}

Primary data were collected by administration of pretested questionnaire to respondents whereas secondary data were collected from District Agriculture Development Office (DADO) profile of Chitwan, reports and publications from Ministry of Agriculture Development (MOAD), Department of Hydrology and Meteorology (DHM) and Central Bureau of Statistics (CBS). Survey was conducted during October-November 2017.

\section{Methods and Techniques of Data Analysis}

Data entry and analysis were done by using Statistical Package for Social science (SPSS 21.0 Version), STATA (Version 12.0) and Microsoft Excel-2013. Both descriptive and analytical methods were used to analyze data.

\section{Result and Discussion}

\section{Adaptations Strategies on Climate Change in Maize Cultivation}

Majority of respondents $(86.7 \%)$ were found to adopt any one of the adaptation strategies whereas very few (13.3\%) did not adopt any strategies because of various reasons. Major strategies followed by farmers were mainly grouped into 11 different categories (Table 1). Among these strategies change in planting time, change in planting method, fertilizer management, shifting cultivation and agroforestry were found statistically significant across study areas.

The study showed that change in crop variety was most commonly adapted strategy (46.2\%). Rampur yellow, Rampur composite, Arun, Khumaltar and Sathiya, were varieties of maize used by Non-Chepang whereas Chepang were found to change variety to Arun variety from their local one. About 37.5 percent of farmers of the study area change their planting time out of which 26 percent were Chepang and 48.1 percent were Non-Chepang. About 6 percent and 51.9 percent of Chepang and Non-Chepang respondent changed planting method respectively. Fertilizer management was adaptation strategy adopted by 30.8 
percent of respondent. Most of the respondents were found to shift their fertilizer management from using only FYM to using of chemical fertilizers like urea, diammonium phosphate (DAP) and potash along with manure. Shifting cultivation was found to be adopted by 7 percent of respondents in which all respondents were Chepang. About 40.4 percent of respondents were found to adopt agroforestry as adaptation strategy. Mix cropping was found to be adopted by 66.3 percent of respondents of study area. Strategies followed by respondents were mainly based on their experience. Most of them were indigenous type whereas some found to be modern types.

\section{Impact of Climatic Variables on Area, Production and Productivity of Maize}

Analysis of climatic variables in productivity, production and area of maize cultivation was done taking series of maximum temperature, minimum temperature and total annual rainfall of 12 years (2003-2016 AD) of Chitwan district. Study showed that total rainfall has a positive impact on all three factors i.e. Productivity, production and area (Table 2). Both maximum and minimum temperature found to have a positive impact on productivity whereas negative impact on production and area. In contrast, average temperature found to have a negative impact on productivity whereas a positive effect on production and area.

Table 1: Adaptations strategies on climate change in maize cultivation

\begin{tabular}{|c|c|c|c|c|c|}
\hline Variable & & Chepang $(n=60)$ & Non-Chepang $(n=60)$ & $\begin{array}{l}\text { Total } \\
(\mathrm{N}=120)\end{array}$ & Chi-Square \\
\hline \multirow{2}{*}{ Adaptation to climate change } & No & $10(16.7)$ & $6(10.0)$ & $16(13.3)$ & \multirow{2}{*}{0.686} \\
\hline & Yes & $50(83.3)$ & $54(90.0)$ & $104(86.7)$ & \\
\hline \multicolumn{6}{|l|}{ If yes } \\
\hline \multirow{2}{*}{ Change in variety } & No & $30(60.0)$ & $26(48.1)$ & $56(53.8)$ & \multirow{2}{*}{1.467} \\
\hline & Yes & $20(40.0)$ & $28(51.9)$ & $48(46.2)$ & \\
\hline \multirow{2}{*}{ Change in planting time } & No & $37(74.0)$ & $28(51.9)$ & $65(62.5)$ & \multirow{2}{*}{$5.434 * *$} \\
\hline & Yes & $13(26.0)$ & $26(48.1)$ & $39(37.5)$ & \\
\hline \multirow{2}{*}{ Change in harvesting time } & No & $34(68.0)$ & $29(53.7)$ & $63(60.6)$ & \multirow{2}{*}{2.222} \\
\hline & Yes & $16(32.0)$ & $25(46.3)$ & $41(39.4)$ & \\
\hline \multirow{2}{*}{ Change in planting method } & No & $47(94.0)$ & $26(48.1)$ & $73(70.2)$ & \multirow{2}{*}{$26.087 * * *$} \\
\hline & Yes & $3(6.0)$ & $28(51.9)$ & $31(29.8)$ & \\
\hline \multirow{2}{*}{ Weed management } & No & $50(100.0)$ & $52(96.3)$ & $102(98.1)$ & \multirow{2}{*}{1.888} \\
\hline & Yes & $0(0.0)$ & $2(3.7)$ & $2(1.9)$ & \\
\hline \multirow{2}{*}{ Pest management } & No & $49(98.0)$ & $52(96.3)$ & $101(97.1)$ & \multirow{2}{*}{0.269} \\
\hline & Yes & $1(2.0)$ & $2(3.7)$ & $3(2.9)$ & \\
\hline \multirow{2}{*}{ Fertilizer management } & No & $25(50.0)$ & $47(87.0)$ & $72(69.2)$ & \multirow{2}{*}{$16.718 * * *$} \\
\hline & Yes & $25(50.0)$ & $7(13.0)$ & $32(30.8)$ & \\
\hline \multirow{2}{*}{ Shifting cultivation } & No & $42(84.0)$ & $54(100.0)$ & $96(92.3)$ & \multirow{2}{*}{$9.360 * * *$} \\
\hline & Yes & $8(16.0)$ & $0(0.00)$ & $8(7.7))$ & \\
\hline \multirow{2}{*}{ Agro forestry } & No & $18(36.0)$ & $44(81.5)$ & $62(59.6)$ & \multirow{2}{*}{$22.306^{* * *}$} \\
\hline & Yes & $32(64.0)$ & $10(18.5)$ & $42(40.4)$ & \\
\hline \multirow{2}{*}{ Mulching } & No & $48(96.0)$ & $52(96.3)$ & $100(96.2)$ & \multirow{2}{*}{0.06} \\
\hline & Yes & $2(4.0)$ & $2(3.7)$ & $4(3.8)$ & \\
\hline \multirow{2}{*}{ Mix cropping } & No & $18(36.0)$ & $17(31.5)$ & $35(33.7)$ & \multirow{2}{*}{0.237} \\
\hline & Yes & $32(64.0)$ & $37(68.5)$ & $69(66.3)$ & \\
\hline
\end{tabular}

Notes: Figures in parentheses indicate standard deviation. $* * *$ and ${ }^{* *}$ indicate significant at 1 and 5 percent levels, respectively

Table 2: Climatic variables affecting on area, production and productivity of maize

\begin{tabular}{lllllll}
\hline Variable & \multicolumn{2}{l}{ Productivity } & Production & & Area \\
\cline { 2 - 6 } T_Max & Coeff. & Std. error & Coeff. & Std. error & Coeff. & Std. error \\
T_Min & 3.992 & 35.204 & -912874.1 & 1020172 & -420439 & 526956 \\
T_Avg & 4.132 & 35.159 & -935547.4 & 1018872 & -429629.1 & 526284.6 \\
Total_rain & -8.29 & 70.30 & $1870420 * * *$ & 2037124 & 858982.5 & 1052249 \\
Summary statistics & 0.0003 & 0.0002 & 32.981 & 7.179 & $13.719 * * *$ & 3.7081 \\
N & 12 & & & & 12 \\
F(4, 7) & 0.52 & 12 & & $4.29 * *$ & 0.046 \\
Prob> F & 0.723 & $6.62 * *$ & & 0.7101 \\
R-squared & 0.230 & 0.0157 & & 0.5445 & \\
Adj R-squared & -0.21 & 0.7910 & &
\end{tabular}




\section{Determinants of Climate Change Adoption}

Among various explanatory variables affecting climate change adaptation on maize cultivation being head of household, having knowledge about climate change and numbers of economically active members of the family were found positively significant.

The study shown in Table 3 revealed that if the respondent is head of household then the probability of climate change adoption increases by 12.1 percent. This is consistent with the finding of Maddison (2006), who reported that being the head of the household increases the probability of farmer to adopt for climatic changes. This perhaps might be due to respondent's control on household resources.

The likelihood to adapt to climate change increases by 10.7 percent if the respondent had heard about climate change than from the one who had not heard about it at all. Obayelu, Adepoju and Idowu (2014) also reported farmer's having more information about climate change has more chances for climate change adaptation.

The study implies that the possibility of climate change adaptation increases by 4.1 percent with an increase in the number of economically active member in a family by 1 . This is in line with the findings of Apata (2011) which assumes that a large family size is normally associated with a higher labor endowment, which would enable a household to accomplish various agricultural tasks, especially during peak seasons.

\section{Factors Affecting Adaptation Strategies to Be Adopted by The Farmers in Study Area to Cope Climate Change Impact \\ Eight different strategies as models were used to access some explanatory variables that determined on different adaptation strategies adopted (Table 4). Seemingly Unrelated Regression (SUR) analysis revealed education of household head, economically active member of household, involvement in extension/ training and production of maize were major positively significant explanatory variables in farmer's decision for adaptation of different climate change combating strategies. Age, gender of household head and involvement in an organization were major negatively significant explanatory variables}

Table 3: Factors affecting respondent's climate change adaptation strategy

\begin{tabular}{|c|c|c|c|c|}
\hline Variables & coeff & Std error & $\mathbf{P}(\mathbf{z})$ & $d y / d x$ \\
\hline HHH\# & $1.457 * *$ & 0.716 & 0.042 & $0.121 * *$ \\
\hline AGE HНH & -0.145 & 0.023 & 0.520 & -0.001 \\
\hline GENDER HHH & 1.151 & 1.025 & 0.261 & 0.129 \\
\hline EDU НHН & 0.040 & 0.897 & 0.657 & 0.003 \\
\hline TOTAI HH & -0.189 & 0.262 & 0.469 & -0.014 \\
\hline HEARD CC\# & $1.317 *$ & 0.684 & 0.054 & $0.107 *$ \\
\hline ACCESS CREDIT\# & -0.508 & 0.808 & 0.530 & -0.034 \\
\hline EXTTRAIN\# & 0.865 & 0.918 & 0.346 & 0.054 \\
\hline ACCESS ELECTY\# & $1.261^{*}$ & 0.721 & 0.080 & 0.132 \\
\hline ЕСОНН & $0.532 *$ & 0.315 & 0.091 & $0.041 *$ \\
\hline Log PRODMAIZE & -0.636 & 0.469 & 0.175 & -0.048 \\
\hline LSU & 0.228 & 0.179 & 0.202 & 0.017 \\
\hline \multicolumn{5}{|l|}{ Summary Statistics } \\
\hline $\mathbf{N}$ & & \multicolumn{3}{|c|}{120} \\
\hline${\operatorname{LR~} \operatorname{chi}^{2}(10)}$ & & \multicolumn{3}{|c|}{16.62} \\
\hline Prob $>$ chi $^{2}$ & & \multicolumn{3}{|c|}{0.164} \\
\hline Log likelihood & & \multicolumn{3}{|c|}{-38.808} \\
\hline Pseudo $\mathbf{R}^{2}$ & & \multicolumn{3}{|c|}{0.1876} \\
\hline Area under ROC curve & & \multicolumn{3}{|c|}{0.790} \\
\hline Correct Classified & & \multicolumn{3}{|c|}{$85.83 \%$} \\
\hline
\end{tabular}

Table 4: Dependent variables used in seemingly unrelated regression

\begin{tabular}{ll}
\hline Models & Dependent Variable \\
\hline Model 1 as strategy of maize variety change & Change maize verities (Yes=1) \\
Model 2 as strategy of planting time change & Planting time change (Yes=1) \\
Model 3 as strategy of harvesting time change & Harvesting time change (Yes $=1)$ \\
Model 4 as strategy of planting method change & Planting method change (Yes=1) \\
Model 5 as strategy of fertilizer management & Fertilizer management (Yes $=1)$ \\
Model 6 as strategy of shifting cultivation & Shifting cultivation (Yes=1) \\
Model 7 as strategy of agroforestry & Agroforestry (Yes=1) \\
Model 8 as strategy of mix cropping & Mix cropping (Yes=1) \\
\hline Source: Household survey, 2017 in Shaktikhor and Fulbari. &
\end{tabular}


Table 5: Determinants of farmer's decision to adopt different adaptation strategies adopted by farmers

\begin{tabular}{|c|c|c|c|c|c|c|c|c|}
\hline Variables $^{1}$ & $\begin{array}{l}\text { Model1 } \\
(\mathrm{dy} / \mathrm{dx})\end{array}$ & $\begin{array}{l}\text { Model2 } \\
(\mathrm{dy} / \mathrm{dx})\end{array}$ & $\begin{array}{l}\text { Model3 } \\
(\mathrm{dy} / \mathrm{dx})\end{array}$ & $\begin{array}{l}\text { Model4 } \\
(\mathrm{dy} / \mathrm{dx})\end{array}$ & $\begin{array}{l}\text { Model5 } \\
(\mathrm{dy} / \mathrm{dx})\end{array}$ & $\begin{array}{l}\text { Model6 } \\
(\mathrm{dy} / \mathrm{dx})\end{array}$ & $\begin{array}{l}\text { Model7 } \\
(\mathbf{d y} / \mathbf{d x}) \\
\end{array}$ & $\begin{array}{l}\text { Model8 } \\
(\mathrm{dy} / \mathrm{dx})\end{array}$ \\
\hline AGE HНH & $\begin{array}{l}-0.004 \\
(0.005)\end{array}$ & $\begin{array}{l}-0.011 * * \\
(0.005)\end{array}$ & $\begin{array}{l}-0.011 * * \\
(0.005)\end{array}$ & $\begin{array}{l}0.003 \\
(0.003)\end{array}$ & $\begin{array}{l}-0.004 \\
(0.004)\end{array}$ & $\begin{array}{l}0.000 \\
(0.001)\end{array}$ & $\begin{array}{l}0.003 \\
(0.005)\end{array}$ & $\begin{array}{l}0.001 \\
(0.005)\end{array}$ \\
\hline GENDER HHH & $\begin{array}{l}0.229 \\
(0.178)\end{array}$ & $\begin{array}{l}-0.2153 \\
(0.224)\end{array}$ & $\begin{array}{l}-0.070 \\
(0.220)\end{array}$ & $\begin{array}{l}-0.476^{*} \\
(0.260)\end{array}$ & & & $\begin{array}{l}-0.134 \\
(0.243)\end{array}$ & $\begin{array}{l}0.305 \\
(0.200)\end{array}$ \\
\hline EDU НHН & $\begin{array}{l}0.006 \\
(0.014)\end{array}$ & $\begin{array}{l}0.038 * * \\
(0.015)\end{array}$ & $\begin{array}{l}0.041 * * \\
(0.016)\end{array}$ & $\begin{array}{l}0.013 \\
(0.010)\end{array}$ & $\begin{array}{l}-0.003 \\
(0.014)\end{array}$ & $\begin{array}{l}0.000 \\
(0.003)\end{array}$ & $\begin{array}{l}0.115 \\
(0.017)\end{array}$ & $\begin{array}{l}-0.017 \\
(0.014)\end{array}$ \\
\hline ЕСОНН & $\begin{array}{l}0.035 \\
(0.037)\end{array}$ & $\begin{array}{l}0.082 * * \\
(0.038)\end{array}$ & $\begin{array}{l}0.0636 * \\
(0.038)\end{array}$ & $\begin{array}{l}-0.028 \\
(0.032)\end{array}$ & $\begin{array}{l}0.013 * * \\
(0.031)\end{array}$ & $\begin{array}{l}0.000 \\
(0.005)\end{array}$ & $\begin{array}{l}-0.0254 \\
(0.038)\end{array}$ & $\begin{array}{l}0.045 \\
(0.039)\end{array}$ \\
\hline LOCATION\# & $\begin{array}{l}-0.097 \\
(0.175)\end{array}$ & $\begin{array}{l}-0.061 \\
(0.176)\end{array}$ & $\begin{array}{l}0.054 \\
(0.178)\end{array}$ & $\begin{array}{c}-0.461 * * * \\
(0.152)\end{array}$ & $\begin{array}{l}0.353 \\
(0.144)\end{array}$ & & $\begin{array}{l}0.384 * * \\
(0.158)\end{array}$ & $\begin{array}{l}0.332 * * \\
(0.161)\end{array}$ \\
\hline MIGRATION\# & $\begin{array}{l}0.108 \\
(0.110)\end{array}$ & $\begin{array}{l}0.364 * * * \\
(0.101)\end{array}$ & $\begin{array}{l}0.365^{* * *} \\
(0.106)\end{array}$ & $\begin{array}{l}-0.076 \\
(0.815)\end{array}$ & $\begin{array}{l}-0.003 \\
(0.099)\end{array}$ & $\begin{array}{l}0.033 \\
(0.031)\end{array}$ & $\begin{array}{l}-0.214^{*} \\
(0.111)\end{array}$ & $\begin{array}{l}-0.191 * \\
(0.105)\end{array}$ \\
\hline EXTRAIN\# & $\begin{array}{l}0.152 \\
(0.130)\end{array}$ & $\begin{array}{l}0.113 \\
(0.133)\end{array}$ & $\begin{array}{l}0.172 \\
(0.135)\end{array}$ & $\begin{array}{l}0.2602 * \\
(0.138)\end{array}$ & $\begin{array}{l}-0.070 \\
(0.113)\end{array}$ & $\begin{array}{l}0.026 \\
(0.040)\end{array}$ & $\begin{array}{l}-0.093 \\
(0.136)\end{array}$ & $\begin{array}{l}-0.1971 \\
(0.129)\end{array}$ \\
\hline INV ORG\# & $\begin{array}{l}-0.020 \\
(0.150)\end{array}$ & $\begin{array}{l}0.040 \\
(0.154)\end{array}$ & $\begin{array}{l}0.099 \\
(0.147)\end{array}$ & $\begin{array}{l}-0.474 * \\
(0.271)\end{array}$ & $\begin{array}{l}-0.144 \\
(0.127)\end{array}$ & $\begin{array}{c}-0.301 * * \\
(0.150)\end{array}$ & $\begin{array}{l}-0.126 \\
(0.153)\end{array}$ & $\begin{array}{c}-0.228 * * \\
(0.107)\end{array}$ \\
\hline LSU & $\begin{array}{l}0.165 \\
(0.027)\end{array}$ & $\begin{array}{l}0.005 \\
(0.032)\end{array}$ & $\begin{array}{l}0.013 \\
(0.029)\end{array}$ & $\begin{array}{l}-0.034 \\
(0.028)\end{array}$ & $\begin{array}{l}-0.039 \\
(0.024)\end{array}$ & $\begin{array}{l}-0.0006 \\
(0.0051)\end{array}$ & $\begin{array}{l}0.0315 \\
(0.029)\end{array}$ & $\begin{array}{l}0.022 \\
(0.028)\end{array}$ \\
\hline LogPRODMAIZE & $\begin{array}{l}0.110^{*} \\
(0.066) \\
\end{array}$ & $\begin{array}{l}-0.033 \\
(0.663) \\
\end{array}$ & $\begin{array}{l}-0.030 \\
(0.065) \\
\end{array}$ & $\begin{array}{l}-0.035 \\
(0.028) \\
\end{array}$ & $\begin{array}{l}0.098 \\
(0.068) \\
\end{array}$ & $\begin{array}{l}-0.001 \\
(0.012) \\
\end{array}$ & $\begin{array}{l}-0.098 \\
(0.67) \\
\end{array}$ & $\begin{array}{l}-0.006 \\
(0.059) \\
\end{array}$ \\
\hline \multicolumn{9}{|l|}{ Summary Statistics } \\
\hline $\mathbf{N}$ & 104 & 104 & 104 & 104 & 104 & 104 & 104 & 104 \\
\hline LR $\operatorname{chi}^{2}(12)$ & 13.60 & $28.36 * *$ & $26.52 * * *$ & $45.57 * * *$ & $23.81 * * *$ & $19.89 * *$ & $31.53 * * *$ & $16.53 *$ \\
\hline Prob $>$ chi $^{2}$ & 0.192 & 0.001 & 0.003 & 0.000 & 0.004 & 0.011 & 0.001 & 0.0885 \\
\hline Log likelihood & -64.980 & -54.63 & -56.48 & -40.573 & -52.286 & -18.257 & -54.388 & \\
\hline Pseudo $\mathbf{R}^{2}$ & 0.0947 & 0.21 & 0.190 & 0.359 & 0.186 & 0.3526 & 0.225 & 0.124 \\
\hline Area under ROC curv & 0.702 & 0.799 & 0.795 & 0.879 & 0.782 & 0.875 & 0.808 & 0.709 \\
\hline Correct Classified & $62.50 \%$ & $74.04 \%$ & $72.12 \%$ & $78.85 \%$ & $73.08 \%$ & $94.23 \%$ & $78.85 \%$ & $70.19 \%$ \\
\hline
\end{tabular}

Age of the household head was found negatively significant on adoption decision to change planting time and harvesting time. Keeping other factors constant increase in the age of household head by one year, the probability of adaptation to climate change by changing planting time and harvesting time both decreases by 1.1 percent. The similar outcome had been found and explained in an article written by Mohammed, Wolfgang and Jason (2014) and Obayelu, Adepoju and Idowu (2014).

The probability to change in planting method as adaptation strategy decreases by 47 percent if the house is headed by male than female. This is in consisting with the finding of Nhemachena and Hassan (2007) which reported femaleheaded household are more likely to adopt climate change adaptation strategies.

Increasing in year of schooling of the household head by one year, the possibility of changing planting time and harvesting time increases by 3.8 and 4.1 percent respectively. This finding can be supported by Maddison (2006), who stated that educated and experienced earners are expected to have more knowledge and information about climate change and agronomic practices that they can use in response.

Analysis revealed that if the number of economically active member increase by 1 , the likelihood to adopt change in planting time, change in harvesting time and fertilizer management increases by 8.2 percent, 6.3 percent and 1.3 percent respectively. Gbetibouo (2009) reported that increase in household size has a positive influence on adaptation strategies. Teklewold, Dadi, Yami and Dana (2006) also stated that higher household size reduces labor force constraints and influence the adaptation of new technology positively.

Likelihood to adopt agroforestry and mix cropping increases by 38.4 percent and 33.2 percent if it is Shaktikhor than Fulbari. In contrast, the likelihood to change planting method decreases by 46 percent in Shaktikhor than in Fulbari.

If the respondent had internally migrated to particular place then likelihood to adopt change in planting time and harvesting time increases by 36.4 and 36.5 percent respectively whereas probability to adopt agroforestry and

\footnotetext{
${ }^{1}$ Total 10 explanatory variables were used to gauge the different adaptation strategies adopted by rice producing farmers in the context of climate change.
} 
mix cropping decreases by 21.4 percent and 19.1 percent respectively.

If the member of a family were involved in extension or training than the possibility to change in planting method as an adaptation method increases by 26 percent. Training or any other contact with extension might provide information about the impacts of climate change, enhances knowledge of farmers, ultimately lead to the adoption of climate change adaptation strategies. Maddison (2006) and Apata, Sameul and Adeola (2009) in South Western Nigeria also reported a similar type of result which revealed that provision of extension facilities increases the probability of practicing various adaptation strategies by farmers.

The study implies that if the family member was involved in an organization then the probability of changing planting method, agroforestry and mix cropping decreases by 47.4 percent, 30.1 and 12.6 percent respectively. The direction of influence of involvement in an organization is also quite startling, as it contradicts the more usual concept that with involvement in organization probability of adoption will increase Uddin, Bokelmann and Ensminger (2014). However, in our study the direction of influence is negative. The implications here might be less importance given by organizations to cover the issues of climate change and its impacts on farmer's livelihoods, thereby failing to raise awareness among the members regarding the subject.

Increase in production by $1 \mathrm{~kg}$ found to increase the probability to change crop variety by 11 percent. It is obvious that as the production increases farm income also increases. Increase in farm income leads to adopting different possible adaptation strategies. Deressa et al. (2009) also supported that increase in farm income increases the probability of adaptation.

\section{Conclusion}

In each area, farmers were found to adopt different strategies to mitigate climate change negative impacts and to sustain their yield. Among different adaptation strategies, change in planting time, change in planting method, fertilizer management, shifting cultivation and agro forestry were found statistically significant across surveyed areas. Total rainfall had a positive impact on all three factors i.e. productivity, production and area whereas average temperature found to have a negative impact on productivity whereas a positive effect on production and area. Climate change adaptation on maize was significantly affected by being head of household, having knowledge about climate change and number of economically active members in the family. Education of household head, economically active member in the household, an involvement in extension/ training and production were major positively significant explanatory variables in farmer's decision for adaptation of different climate change combating strategies. Age, gender of household head and involvement in an organization were major negatively significant explanatory variables. Hence, farmer level exercises for facing climate change need to be nicely considered by integrating them in policies, strategies and technology development. Moreover, immediate improvement mechanism for government and nongovernment sector is mandatory to halt dwindling maize production.

\section{Author's Contribution}

R.R. Kattel designed the research plan; A.P. Subedi performed experimental works \& collected the required data. P. Sharma analysed the data \& prepared the manuscript. All authors critically revised, finalized and approved the manuscript.

\section{Conflict of Interest}

The authors declare that there is no conflict of interest with present publication.

\section{Acknowledgements}

Authors are thankful to 'Participatory Biodiversity and Climate Change Assessment for Integrated Pest Management in the Chitwan-Annapurna Landscape' project of Nepal, funded by USAID, for providing research grant for this research. Highly acknowledged towards the farmers involved in the survey.

\section{References}

Apata TG, Samuel KD and Adeola AO (2009) Analysis of climate change perception and adaptation among arable food crop farmers in South Western Nigeria. In International Association of Agricultural Economists' 2009 Conference, Beijing, China.

Bannayan M, Hoogenboom G and Crout NMJ (2004). Photothermal impact on maize performance: a simulation approach. Ecological Modeling 180: 277-229. DOI: $\underline{10.1016 / j . e c o l m o d e l .2004 .04 .022 ~}$

CBS (2003) Central Beauro of Statistics, Government of Nepal, Kathmandu.

Deressa TT, Hassan RM, Ringler C, Alemu T and Yesuf M (2009) Determinants of farmers' choice of adaptation methods to climate change in the Nile Basin of Ethiopia. Global Environmental Change 19(2): 248-255. DOI: $\underline{10.1016 / j . g l o e n v c h a .2009 .01 .002}$

Easterling WE (1996) Adapting North American agriculture to climate change in review. Agricultural and Forest Meteorology 80(1). DOI: 10.1016/0168-1923(95)02314-3

Ebi KL, Woodruff R., Von HA and Corvalan C (2007) Climate change-related health impacts in the Hindu KushHimalayas 4(3):264-270. DOI: 10.1007/s10393-007$\underline{0119-\mathrm{Z}}$

Gbetibouo GA (2009)Understanding farmers' perceptions and adaptations to climate change and variability, the case of the Limpopo Basin, South Africa. IFPRI Discussion Paper No. 00849. Environment and Production Technology Division, International Food Policy Research Institute. 
Joshi NP, Maharjan, KL and Piya L (2001) Effect of climate variables on yield of major food crops in Nepal-A timeseries analysis. MPRA.

Maddison D (2006)The perception and adaptation to climate change in Africa. CEEPA Discussion Paper No. 10. Centre for Environmental Economics and Policy in Africa, University of Pretoria. DOI: $10.1596 / 1813-9450-4308$

Maolecorft (2011) Climate change risk report.

MoAD (2016) Statistical information on Nepalese agriculture .

Mohammed NU, Wolfgang B and Jason SE (2014) Factors affecting farmers' adaptation strategies to environmental degradation and climate change effects: a farm level study in Bangladesh.Climate 2: 223-241. DOI: $\underline{10.3390 / \text { cli2040223 }}$

Nayava, JL and Gurung DB (2010) Impact of climate change on product and productivity:a case study of maize research and development in Nepal. The Journal of Agriculture and Environment 11: 1-11. DOI: 10.3126/aej.v11i0.3653

Obayelu OA, Adepoju AO and Idowu T (2014) Factors influencing farmers' choices of adaptation to climate change in Ekiti State, Nigeria. Journal of Agriculture and
Environment for International Development 108(1): 3-16. DOI: $\underline{10.5958 / 2230-7338.2015 .00022 .1}$

Piya L, Maharjan KL, and Joshi NP (2013) Determinants of adaptation practices to climate change by Chepang households in the rural Mid-Hills of Nepal. Regional Environmental Change.13(2): 437-447. DOI: $\underline{10.1007 / \mathrm{s} 10113-012-0359-5}$

Shrestha, AB, Wake CP, Dibb JE and Mayewski P (2000) A. Precipitation fluctuations in the Nepal Himalaya and its vicinity and relationship with some large-scale climatological parameters. International Journal of Climatology 20(3);317-327. DOI: $10.1002 /(\mathrm{SICI}) 1097-$ 0088(20000315)20:3<317::AID-JOC476>3.0.CO;2-G

Teklewold H, Dadi L, Yami A and Dana N (2006) Determinants of adoption of poultry technology: a double-hurdle approach. Livestock research for rural development 18(3).

Uddin MN, Bokelmann W and Entsminger JS (2014) Factors affecting farmers' adaptation strategies to environmental degradation and climate change effects: A farm level study in Bangladesh. Climate 2(4): 223-241. DOI: $\underline{10.3390 / \mathrm{cli} 2040223}$ 